\title{
Effect of Root Stocks and Grafting Techniques on Quality of Tomato (Solanum lycopersicum L.) under Polyhouse Conditions
}

\author{
Amirullah Mokhles*, Pardeep Kumar, Parveen Sharma and Vandana Thakur \\ Department of Vegetable Science and Floriculture, CSK Himachal Pradesh Krishi \\ Vishvavidalaya, Palampur - 176 062, India \\ *Corresponding author
}

\section{A B S T R A C T}

\section{Keywords}

Tomato, Grafting techniques,

Rootstock, Scion,

Bacterial wilt,

Protected

environment

Article Info

Accepted:

04 June 2019

Available Online:

10 July 2019
Tomato is one of the potential vegetable crops both under protected and open field conditions in mid hills of Himachal Pradesh. The production under protected as well as open conditions has suffered in mid hills of HP due to biotic and abiotic stresses. Among biotic stresses bacterial wilt caused by Ralstonia solanacearum is the most devastating disease under protected as well as open field conditions in mid hills of HP which reduces tomato yield to very low levels. Chemical control is not effective and resistant varieties are scanty, therefore, vegetable grafting is the effective alternative to combat this problem. The experiment was conducted during Spring-Summer season 2016 at Palampur to find out bacterial wilt resistant rootstock and for quality traits i.e. TSS, Pericarp thickness and Ascorbic acid content. Three grafting techniques were used and tomato scion grafted on five brinjal and two tomato rootstocks plus control (non-grafted plots). Difference rootstocks and grafting techniques significantly affected the quality traits of tomato. Among the rootstocks RS6 (Palam Pink) had maximum pericarp thickness $(8.14 \mathrm{~mm})$. The treatment RS2 (VI-047335) was recorded highest ascorbic acid content $18.07 \mathrm{mg} / 100 \mathrm{~g}$ in tomato fruits. Maximum TSS of $5.08{ }^{\circ}$ Brix was observed in fruit from plants grafted on rootstock RS1 (VI-045376), which was significantly superior to other rootstocks used in the study. Slant cut grafting was found as best grafting technique in tomato for quality traits. All the rootstocks used in the study showed resistance to bacterial wilt. Control (non-grafted tomato) recorded $67.66 \%$ bacterial wilt disease incidence.

\section{Introduction}

Tomato (Solanum lycopersicum L.), a member of solanaceae family is the most important and widely grown off-season commercial vegetable crop under polyhouse conditions in Himachal Pradesh. It is the world's largest vegetable crop known as productive as well as protective food. It is a rich source of minerals, vitamins, organic acid, essential amino acids, nicotinic acid, pantotheric acid, protein, fat, carbohydrates, iron, phosphorus, Lycopene and Beta-carotene pigments. Protected cultivation is the concept of growing potential crops in the modified natural environment for ensuring optimum growth of the crop plants without any or least stress and hence offers great scope to harness this potential of growing the high value crops by achieving independence of climate and weather, and to 
grow these crops during off -season and in marginal environments. The practice of protected cultivation of vegetable crops is also becoming popular in the hilly regions of the country, which offers a great scope for use of low cost naturally-ventilated polyhouses because of mild climate. Himachal Pradesh is also not an exception to this cultivation and most of the growers in the lower mid hills and mid hills are adopting this technology. As per recent estimates, area under protected cultivation in Himachal Pradesh is approximately 350 hectares (Anonymous 2013). The area under protected cultivation is increasing day by day with interventions of the state and central government funded schemes. However, it occupies an area of 10,370 hectares with the production of 430790 metric tonnes in the state under open field conditions (Anonymous 2015). The production under protected conditions has suffered in mid hills of HP due to biotic and abiotic stresses. Among biotic stresses bacterial wilt caused by Ralstonia solanacearum is the most devastating disease under protected as well as open field conditions in mid hills of HP which reduces tomato yield to very low levels. The disease was first reported in Kangra valley in 1981 on solanaceous crops, and now it become endemic in Kangra and Mandi districts (Sood and Singh, 1992). The chemical control is not effective and resistant varieties are scanty, therefore vegetable grafting is the effective alternative technique to combat this problem (Kumar et al., 2015). Grafting is the union of two or more pieces of living plant tissues that grow as a single plant (Lee and Oda 2003). It is usually used to reduce infections by soil borne pathogens and to enhance tolerance against abiotic stresses such low and high temperature, salt, flooding etc. Vegetable grafting is now common in Asia, parts of Europe and the Middle East. In Korea, about $90 \%$ of the cucurbitaceous vegetable and $30 \%$ of solanaceous vegetable are grafted on various rootstocks (Lee et al., 2010). Grafting tomato scions on compatible rootstocks improves quality parameter of the plant. Grafting scions on resistant root stocks makes it possible to control soil borne disease and increase yield of susceptible cultivar (Lee and Oda, 2003). The use of resistant rootstocks reduces dependence on agrochemicals, so the technique is therefor, considered to be ecofriendly for sustainable vegetable production (Rivard and Louws, 2008). Grafted seedlings were used to induce resistance against low and high temperature (Venema et al., 2008), enhance nutrient uptake (Colla et al., 2010), increase synthesis of endogenous hormones (Dong et al., 2008) and improve water use efficiency (Rouphael et al., 2008). The main purpose of grafting seedlings is to increase the yield and tolerance to biotic and abiotic stresses. This technology was ignored because the focus of the breeders remained only to develop suitable varieties or hybrids resistant to biotic stresses. Since grafting gives increased disease tolerance and vigour to crops so it will be useful in the low-input sustainable horticulture of the future. Since, there is no other alternative method or strategy to control serious diseases like bacterial wilt, grafting has become an essential technique for the production of repeated crops of fruit bearing vegetables grown in polyhouse. The recent studies showed that the use of the suitable rootstocks will help to improve biotic and abiotic stresses in tomato has positively increased the yield, particularly under greenhouse conditions. Further research studies more focused on physiological aspects in addition to yield and quality parameters of tapping the potential of the crop plant (tomato) as with more benefits and manage bacterial wilt. Therefore, keeping in view the above stated facts, the present investigation entitled "Effect of root stocks and grafting techniques on yield and quality of tomato (Solanum lycopersicum L.) under protected environment", was planned with the following 
objective, to find out best rootstock for quality of tomato and bacterial wilt resistant rootstock.

\section{Materials and Methods}

The present investigation was undertaken at Palampur during Spring-Summer season 2016. The experimental material for the present study comprised of five brinjal and two tomato rootstocks and one tomato hybrid used as a scion plus control (non-grafted plots). Commercial tomato hybrid GS-600 was used as scion. The different bacterial wilt resistant rootstocks were procured from AVRDCTaiwan, CSKHPKV-Palampur and IIHRBengaluru. Whereas, the scion of tomato cultivar was commercial private sector hybrid and recommended for cultivation under protected condition (Table 1).

Three grafting methods were followed, including: tongue grafting (G1), cleft grafting (G2) and slant cut grafting (G3). The nursery of the rootstocks and scion was raised in plug trays and in disposable cups by using soil-less media (Cocopeat: Perlite: Vermiculite in the ratio of $3: 1: 1$ ). Rootstocks were sown on 10th Feb. 2016, whereas, sowing of scion variety was done on 24th Feb. 2016 in growth chamber. The width of the bed was kept at 90 $\mathrm{cm}$, whereas length was kept at $2 \mathrm{~m}$. The plants were planted at $70 \mathrm{~cm}$ row to row and $30 \mathrm{~cm}$ plant to plant spacing thus accommodating 12 plants per bed. The beds were covered by plastic mulch and 12 plants in each control plot (one plot in every replication) were transplanted at inter row distance of $70 \mathrm{~cm}$ and plant to plant distance of $30 \mathrm{~cm}$ in Randomized Block Design with three replications in $250^{\mathrm{m}}$ modified naturally ventilated polyhouse. Observations were recorded on five plants were randomly selected from each treatment in each replication viz.,TSS $\left({ }^{\circ}\right.$ Brix), Pericarp thickness (mm) and ascorbic acid content $\mathrm{mg} / 100$ gand for screening of rootstocks against bacterial wilt (Ralstonia solanacearum) was done. The observations were recorded on bacterial wilt incidence at weekly intervals under protected conditions. The data regarded above mentioned characters were averaged and subjected to analysis of variance (Pane and Sukhatme, 2000).

\section{Results and Discussion}

A scrutiny of data in Table 2 and 3 that rootstocks and grafting techniques significantly affected pericarp thickness. Among the rootstocks RS6 (Palam Pink) had maximum pericarp thickness $(8.14 \mathrm{~mm})$, followed by Arka Keshav (RS5) $(8.10 \mathrm{~mm})$. The data recorded for quality traits are presented in Table 3 that cleft grafting (G2) resulted in maximum pericarp thickness $(6.92$ $\mathrm{mm})$, followed by slant cut grafting (G3) $(6.88$ $\mathrm{mm})$ pericarp thickness and non-grafted recorded $(8.02 \mathrm{~mm})$ pericarp thickness. Similar findings were recorded by Kumar et al., (2016). The treatment RS2 (VI-047335) had highest ascorbic acid content 18.07 $\mathrm{mg} / 100 \mathrm{~g}$ in tomato fruits, followed by Arka Nidhi (RS4) (16.27 mg/100g) ascorbic acid content. Generally the quality attributes depend on the compatibility of the scion and stocks. Some rootstocks may give positive results on the quality with particular scion but may give negative results on the other scion. Wahb-Allah (2014) and Al-Harbi et al., (2016) found reduced ascorbic acid in grafted plants. Balliu et al., (2008) and Kumar et al., (2016) found higher ascorbic acid content in grafted plants as compared to non-grafted plants. Gebologlu et al., (2011) and Chen and Wang (2016) found no significantly difference for quality attributes among grafted and nongrafted plants. Maximum TSS of $5.08{ }^{\circ}$ Brix was recorded in fruit from plants grafted on rootstock RS1 (VI-045376), which was significantly superior to other rootstocks used in the study. 
Table.1 List of rootstocks

\begin{tabular}{|l|l|l|l|}
\hline Rootstocks & Symbol & Source & Salient features \\
\hline VI-045376 (Brinjal) & (RS1) & AVRDC, Taiwan & Resistant to bacterial wilt \\
\hline VI-047335 (Brinjal) & (RS2) & AVRDC, Taiwan & Resistant to bacterial wilt \\
\hline VI-034845 (Brinjal) & (RS3) & AVRDC, Taiwan & Resistant to bacterial wilt \\
\hline Arka Nidhi (Brinjal) & (RS4) & IIHR-Bengaluru & Resistant to bacterial wilt \\
\hline Arka Keshav (Brinjal) & (RS5) & IIHR-Bengaluru & Resistant to bacterial wilt \\
\hline Palam Pink (Tomato) & (RS6) & CSKHPKV, Palampur & Resistant to bacterial wilt \\
\hline Palam Pride (Tomato) & (RS7) & CSKHPKV, Palampur & Resistant to bacterial wilt \\
\hline
\end{tabular}

Table.2 Effect of rootstocks on quality traits under protected condition

\begin{tabular}{|l|c|c|c|}
\hline Grafting techniques & $\begin{array}{c}\text { Pericarp thickness } \\
(\mathbf{m m})\end{array}$ & $\begin{array}{c}\text { Ascorbic acid } \\
\text { content } \mathbf{~ m g} / \mathbf{1 0 0 g}\end{array}$ & TSS $\left({ }^{\circ}\right.$ Brix $)$ \\
\hline Tongue grafting (G1) & 6.73 & 12.58 & 4.10 \\
\hline Cleft grafting (G2) & 6.92 & 13.20 & 4.16 \\
\hline Slant cut grafting (G3) & 6.88 & 13.54 & 4.27 \\
\hline Control (non-grafting) & 8.02 & 15.43 & 4.39 \\
\hline CD $(\mathbf{P = 0 . 0 5 )}$ & $\mathbf{0 . 1 1}$ & $\mathbf{0 . 0 9}$ & $\mathbf{0 . 0 2}$ \\
\hline
\end{tabular}

Table.3 Effect of rootstocks on quality traits under protected environment

\begin{tabular}{|l|c|c|c|}
\hline Rootstocks & $\begin{array}{c}\text { Pericarp thickness } \\
(\mathbf{m m})\end{array}$ & $\begin{array}{c}\text { Ascorbic acid } \\
\text { content } \mathbf{~ m g} / \mathbf{1 0 0 g}\end{array}$ & TSS $\left({ }^{\circ}\right.$ Brix $)$ \\
\hline VI-045376 (RS1) & 7.44 & 15.54 & 5.08 \\
\hline VI-047335 (RS2) & 7.87 & 18.07 & 4.74 \\
\hline VI-034845 (RS3) & 7.63 & 12.93 & 4.71 \\
\hline Arka Nidhi (RS4) & 7.90 & 16.27 & 4.59 \\
\hline Arka Keshav (RS5) & 8.10 & 13.48 & 4.81 \\
\hline Palam Pink (RS6) & 8.14 & 14.49 & 4.68 \\
\hline Palam Pride (RS7) & 7.67 & 14.05 & 4.79 \\
\hline control (non-grafting) & $\mathbf{0 . 0 4}$ & $\mathbf{0 . 0 3}$ & $\mathbf{0 . 0 1}$ \\
\hline CD (P=0.05) & $\mathbf{0 . 1 6}$ & $\mathbf{0 . 1 4}$ & $\mathbf{0 . 0 4}$ \\
\hline
\end{tabular}

Slant cut grafting (G3) resulted in maximum TSS of $4.27{ }^{\circ}$ Brix which was followed by cleft grafting (G2) and tongue grafting (G1) having 4.16 and $4.10^{\circ}$ Brix.

Whereas, non- grafted plants were (control) recorded with maximum TSS of $4.39{ }^{\circ}$ Brix. The results are in accordance with the findings of Al-Harbi et al., (2016), Chen and
Wang (2016) and Kumar et al., (2016). Weekly recorded on bacterial showed wilting symptoms while all the rootstocks were resistance to bacterial wilt. Therefore, less survival rate of control/ non-grafted plants was due to the incidence of bacterial wilt. Therefore, from this study it may be inferred that grafting can be an effective strategy to manage bacterial wilt incidence in tomato. 


\section{References}

Al-Harbi, A., Hejazi, A., Al-Omran, A. 2016. Responses of grafted tomato (Solanum lycopersiocon L.) to abiotic stresses in Saudi Arabia. Saudi Journal of Biological Sciences, 23(1): 2-7.

Anonymous. 2013. Urban and Peri-urban Agriculture. National Academy of Agricultural Sciences Policy Paper: 67.

Anonymous. 2015. Indian Horticulture Database-2014. National Horticulture Broad, Ministry of Agriculture, Government of India, Gurgaon, Haryana.

Balliu, A., Vuksani, G., Kaçiu, S., Nasto, T. and Haxhinasto, L. 2008. Grafting effects on tomato growth rate, yield and fruit quality under saline irrigation water. Acta Horticulture, 801: 11611166.

Chen, W.Y. and Wang, J.F. 2016. Grafting tomatoes for production in the hot-wet season. Conference Paper1-12.

Colla, G., Rouphael, Y., Leonardi, C. and Bie, Z. 2010. Role of grafting in vegetable crops grown under saline conditions. Science Horticulture, 127: 147-155.

Dao-Feng, D., Zhi-Ping, C., Xiu-Hui, W., Ju, H. and Gullino, M.L. 2007. Effect of nematode resistant rootstocks on growth characteristics and yields of tomato. Acta Horticulturae, 34(5): 1305-1308.

Dong, H.H., Niu, Y.H., Li, W.J. and Zang, D.M. 2008. Effect of cotton rootstock on endogenous cytokinins and abscisic acid in xylem sap and leaves in relation to leaf senescence. Journal of Experimental Botany, 59: 1295-1304.

Gebologlu, N., Yılmaz, E., Çakmak, P., Aydın, M., and Kasap, Y. 2011. Determining of the yield, quality and nutrient content of tomatoes grafted on different rootstocks in soilless culture. Academic Journals, 6(10): 2147-2153.

Kumar, P., Edelstein, M., Cardarelli, M.,
Ferri, E. and Colla, G. 2015. Grafting affects growth, yield, nutrient uptake, and partitioning under cadmium stress in tomato. Horticulture Science, 50(11): 1654-1661.

Kumar, P., Rana, S., Sharma, P. and Negi, V. 2015. Vegetable grafting: a boon to vegetable growers to combat biotic and abiotic stresses. Himachal Journal of Agricultural Research, 41(1): 1-5.

Kumar, P., Rana, S., Sharma, P., Singh, A. and Upadhyay, S.K. 2016. Evaluation of chilli and brinjal rootstocks for growth, yield and quality of bell pepper (Capsicum annuum L. var. grossum Sendt.) under protected conditions. Agriculture Research Journal, 53(2): 180-183.

Kumar, P., Sharma, P. and Vats, B. 2016. Effect of grafting tomato on different rootstocks under protected environment in mid hills of NW Himalayan region. Agric. Sci. Digest, 37(1) 81-82.

Lee, J. and Oda, M. 2003. Grafting of herbaceous vegetable and ornamental crops. Horticulture Reviews, 28: 61124.

Lee, J.M. 1994. Cultivation of grafted vegetables I. Current status, grafting methods, and benefits. Horticulture Science, 29(4): 235- 239.

Lee, J.M., Kubota, C., Tsao, S.J., Bie, Z., Echevarria, P.H., Morra, L. and Oda, M. 2010. Current status of vegetable grafting: Diffusion, grafting techniques, automation. Scientia Horticulturae, 127(2) 93-105.

Panse, V.G. and Sukkhatme, P.V. 2000. Statistical methods for agricultural workers. Indian Council of Agricultural Research, New, Delhi, India. Pp. 157165.

Rivard, C.L. and Louws, F.J. 2008. Grafting to manage soil-borne diseases in Heirloom tomato production. Horticulture Science, 43(7): 2104-2111. 
Rouphael, Y., Schwarz, D., Krumbein, A. and Colla, G. 2008. Yield, mineral composition, and water relation water use efficiency of grafted miniwatermelon plants under deficit irrigation. Horticulture Science, 43: $730-736$.

Sood, A.K. and Singh, B.M. 1992. Prevalence of bacterial wilt of solanaceous vegetables in the mid hills sub humid zone of Himachal Pradesh, India. Australian Center for International Research (ACIR), 45: 358-361.
Venema, J.H., Dijk, B.E., Bax, J.M. van, Hasselt, P.R. and Elzenga, J.T.M. 2008. Grafting tomato (Solanum lycopersicum L.) onto the rootstock of a highaccession of Solanum habrochaites improves suboptimal temperature tolerance. Environmental and Experimental Botany, 63: 359-367.

Wahb-Allah, M.A. 2014. Effectiveness of grafting for the improvement of salinity and drought tolerance in tomato (Solanum lecopersicon L.). Asian Journal of crop Science, 6(2): 112-122.

\section{How to cite this article:}

Amirullah Mokhles, Pardeep Kumar, Parveen Sharma and Vandana Thakur. 2019. Effect of Root Stocks and Grafting Techniques on Quality of Tomato (Solanum lycopersicum L.) under Polyhouse Conditions. Int.J.Curr.Microbiol.App.Sci. 8(07): 80-85. doi: https://doi.org/10.20546/ijcmas.2019.807.011 